University of Nebraska - Lincoln

DigitalCommons@University of Nebraska - Lincoln

Faculty Publications: Agricultural Economics

Agricultural Economics Department

8-1-1992

\title{
Agricultural Protection in Developing Countries
}

Lilyan E. Fulginiti

University of Nebraska-Lincoln, Ifulginiti1@unl.edu

Richard K. Perrin

University of Nebraska-Lincoln, rperrin@unl.edu

Follow this and additional works at: https://digitalcommons.unl.edu/ageconfacpub

Part of the Agricultural and Resource Economics Commons

Fulginiti, Lilyan E. and Perrin, Richard K., "Agricultural Protection in Developing Countries" (1992). Faculty Publications: Agricultural Economics. 8.

https://digitalcommons.unl.edu/ageconfacpub/8

This Article is brought to you for free and open access by the Agricultural Economics Department at DigitalCommons@University of Nebraska - Lincoln. It has been accepted for inclusion in Faculty Publications: Agricultural Economics by an authorized administrator of DigitalCommons@University of Nebraska - Lincoln. 


\title{
Agricultural Protection in Developing Countries
}

\author{
Lilyan E. Fulginiti and Jason F. Shogren
}

Countries often have a Jekyll-Hyde relationship with their agricultural sector-policy makers both tax and subsidize agriculture. In the early stages of a country's development, policy makers exploit agriculture through export taxes and overvalued exchange rates. In contrast, agricultural policy in advanced industrial countries has strongly protected domestic producers by means of trade restrictions, direct price or income supports, and public investment.

The present paper explores why farmers are taxed in poor countries and subsidized in rich countries. Using the economic theory of contests to come to an understanding of the incentives for agricultural protectionism, we first sketch a framework for an excludable and rivalrous rent. We then apply this framework to agricultural protectionism in developing countries.

\section{A Contest for Agricultural Protection}

Olson (1982) uses his theory of collective action to explain the dual treatment of agriculture and industry. Benefits of collective lobbying for a rent must be shared among the lobbying groupeither shared equally for a public good or according to some sharing rule for a divisible private good. If there is a great number of potential beneficiaries, the costs of securing the good may not be botne equally by all who benefit. Therefore, there is little incentive to engage in collective lobbying to secure a government rent, and such groups are unorganized or poorly managed. This is so with the agricultural sector in less-developed countries. In comparison, the manufacturing sector has fewer players. There, because of lower transaction costs, the benefits

Fulginiti and Shogren are assistant and associate professots, ter spectively, Department of Economics, Lowa State University, Ames

Todd Sandler, Kyung Hwan Baik, and Richard Perrin provided useful comtikents.

Joumal paper No. J-14786 of the Iowa Agricultural Home Eco. nomics Experiment Station, Project No, 2998. of collective action outweigh the costs, a fact implying strong lobbying to obtain the rent (Bates and Rogerson). But as the transaction costs of forming a collective decrease through improved transportation, education, and information systems, the balance of power can shift. Eventually, the agricultural sector will find it profitable to form an effective collective lobby, which will benefit from govemment subsidies.

If the rent is a private good, excludable and rivalrous in consumption, several other issues become important. For example, if the rent is a direct subsidy to the industrial or the agricultural sector, players within the sector compete to receive support. The overall rent is depleted as one player receives the subsidy. The economic theory of contests becomes a useful framework to further our understanding of such cases (Tullock). Next, we sketch the framework for a rentseeking contest between agricultural and industrial sectors.

By selecting the rent and who receives it, the tegulator plays the key tole in this model (Applebaum and Katz). Let $G_{i}=S_{i}+T_{i}$ be the rent $(i=1,0, \ldots, k)$, where $S_{j}$ is the subsidy won. and $T_{i}$ the tax avoided if the player is victorious. The regulator can award the rent either to industry or agriculture. For each strategy, the regulator's expected utility is represented by

$$
\begin{aligned}
& \phi_{i}= \\
& \pi_{i}\left[X\left(\alpha, G_{i}, \sigma_{x}, W\right), Y\left(\alpha, G_{i}, \sigma_{y}, W\right)\right] U(T R, \xi) \\
& +\left[1-\pi_{i}(\cdot)\right] U(z) \quad i=0,1, \ldots, k_{1}
\end{aligned}
$$

where $\pi_{r}(\cdot)$ is the likelihood of the regulator's remaining in office given the rent-seeking effort of agriculture $X$ and industry $Y$. Rent-seeking efforts depend upon relative strength of the sector $\alpha$, the level of rent $G_{i}$, the sector's sharing rule $\sigma_{x}$ or $\sigma_{y y}$ and political or institutional environment $W$. Let $T R=\beta(X(\cdot)+Y(\cdot))$ be the fraction of rent-seeking expenditures received by the regulator, $0 \leq \beta \leq 1 ; \xi$ the nonmonetary social welfare concerns (possibly zero), and $z$ the regulator's income if she is removed from office. $W$ can be interpreted as the nature of the 
playing field. The regulator's problem is to select the strategy maximizing her expected utility:

$$
\operatorname{Max}\left\{\phi_{0}, \phi_{1}, \ldots, \phi_{k}\right\}
$$

If information is imperfect, groups must decide how much effort to invest to increase the probability of winning the reward. Individual players in the agricultural and the industrial sectors expend efforts, $x_{i}$ and $y_{j}$, to increase the likelihood of winning a subsidy and avoiding a tax. The probability that the agricultural sector wins some rent is $p_{A}(X, \alpha Y \mid W)=\sum_{i=0}^{k-g} p_{i}(\cdot)$, where $X=\sum_{i=1}^{n} x_{i}$ and $Y=\sum_{j=1}^{m} y_{j}$. If $\alpha>1$, manufacturing is more powerful than agriculture; $\alpha<$ I implies the opposite. The strength term represents factors influencing the productivity of rent seeking. We initially assume $\alpha>$ $L$ in developing countries. We justify this assumption by noting Olson's argument that, although in the early stage of a country's economic development the majority of its people engage in agriculture, demand for farm price supports is typically quite weak as a result of the high cost of coordinating farmers' rent-seeking activities. Agricultural populations are relatively uneducated, are scattered over a wide atea, and have poor communication and transportation systems. Benefits from lobbying for higher prices are minimal because a small share of subsistence farmers' production is sold. No other significant groups, such as domestic industries supplying farm inputs, have yet emerged to argue for policies favorable to agriculture.

In contrast, demand for industrial assistance policies is relatively strong. Industrialists are typically better educated than agriculturalists, are based in urban centers, and are relatively small in numbers. The cost of collective political lobbying activity is comparatively low. Two major benefits arise from lobbying against subsidized agricultural prices. First, increased agricultural export earrings increase the supply of foreign exchange, lowering its price. Currency appreciation lowers the local currency price of import-competing manufactures. Second, benefits accrue from the impact of low food prices on wages. Industrialists support workers in resisting food price increases for fear of increased living cost and resulting demands of higher wages. Because urban wage earners have low incomes and a large Engel coefficient, high food prices tend to trigger urban distuption.

Players in agricultural and manufacturing sectors now select first, the optimal sharing rule detailing how the prize will be divided within the sector if victorious, second, the optimal timing of effort (should the group move first or after its opponent has moved?), and third, the level. of effort. If $G$ is a public good, then the sharing rule will not depend upon effort. If $G$ is a divisible prize, as in protectionism, a sharing rule must explicitly examine how the prize will be divided. Let the shares to individuals in the two sectors be

$$
\begin{aligned}
& \sigma_{r}=\frac{x_{i}}{X} \varphi_{x}+\frac{1}{n}\left(1-\varphi_{x}\right) \quad i=[, \ldots, n \\
& \sigma_{r}=\frac{y_{j}}{y^{\prime}} \varphi_{r}+\frac{1}{m}\left(1-\varphi_{y}\right) \quad j=1, \ldots, m,
\end{aligned}
$$

where $\varphi(0 \leq \varphi \leq 1)$ is the weight factor $(\varphi=$ 0 , implying an effort-independent sharing rule, and $\varphi=1$, implying an effort-dependent rule). Baik and Shogren demonstrate that if $n>m$, the larger group (agriculture) will emphasize the effort-independent sharing rule and the other group (manufacturing) will emphasize the effort-dependent sharing rule. Even if the reward is a private good, individuals in the agricultural group will have an incentive to free ride, a fact suggesting less effort in the contest.

Given the optimal sharing rules, players in both agricultural and manufacturing sectors noncooperatively select $x_{i}$ and $y_{i}$ to maximize expected profits:

$$
\begin{array}{ll}
\operatorname{Max}_{r_{i}}\left[p_{A}(X, \alpha Y \mid W) G \sigma_{s}-x_{\mathrm{j}}\right] & i=1, \ldots, n \\
\operatorname{Max}\left[p_{m}(X, \alpha Y \mid W) G \sigma_{y}-y_{j}\right] & j=1, \ldots, m
\end{array}
$$

where $p_{A}(X, \alpha Y \mid W) G=\sum_{i=\mathbb{R}}^{k-g} p_{i} \cdot G_{i}$ and $p_{m}(X$, $\alpha Y \mid W) G=\sum_{i=k-g}^{k} p_{i} \cdot G_{i}$. Figure 1 illustrates the model for the simple case of four rent levelsno rent $\left(G_{0}\right)$, low rent $\left(G_{L}\right)$, high rent $\left(G_{H}\right)$, and very high rent $\left(G_{v}\right)$. The first row in the payoff vectors reflect the regulator's expected utility; the second and third rows are expected payoffs to agriculture and industry.

Given that the contest bias term affects effort, the sector supported by the regulator may well. change as the economy develops. As subsistence farmers become mote commercialized, the share of market production expands, increasing potential benefits from seeking higher production prices. As the farm population declines, their education level rises, and communication and transportation infrastructures in rural areas improve. Rural people may become more sensitive about their relative position in terms of income and standard of living, while the cost of organizing themselves declines. Farmer organiza- 


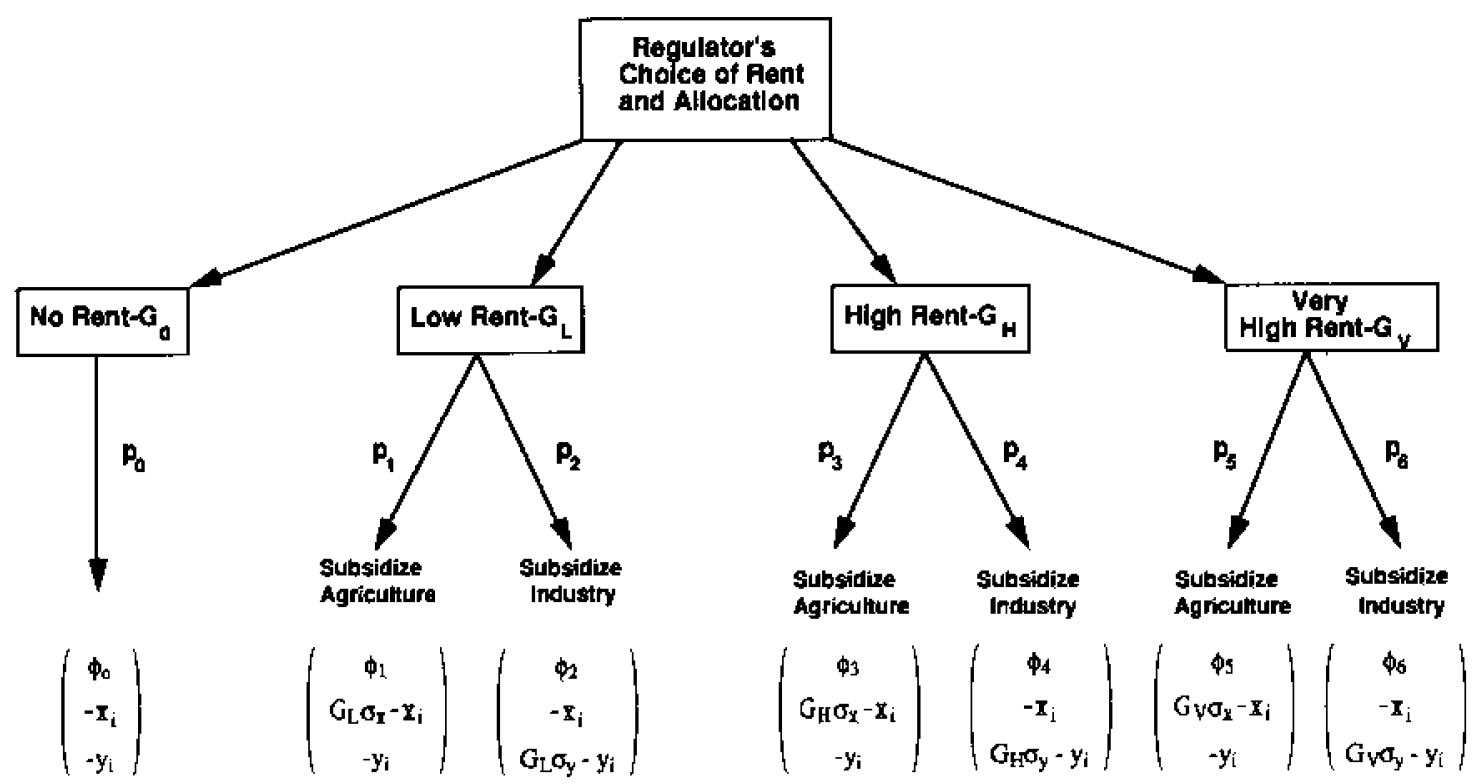

Figure 1. Regulator's choice of actions

tions emerge that, once established, have a vested interest in lobbying not only on behalf of farmers but also on behalf of themselves. The same is true of a new group of manufacturing and service industries producing farm inputs and processing farm outputs. Consequently, the contest bias approaches unity ( $\alpha \rightarrow 1$ ) when agticulture and manufacturing become equally powerful rent seekers.

\section{Agricultural Protectionism in Developing Countries}

Market intervention policies have played a major role in the differential performance of the agricultural sectors of both developing and developed countries. These policies include price supports, taxes, subsidies, tariffs, and exchange-rate market interventions. Agricultural policy in advanced industrial countries has been characterized by strong protection of domestic producers by means of trade restrictions and direct price supports. In contrast, developing countries have exploited agriculture by such means as export taxes and overvalued exchange rates.

Table 1 summarizes average nominal tates of agricultural protection in 33 developed, newly industrialized, and developing countries. The table presents estimares of the degtees of direct and indirect intervention in agricultural com- modities. These protection coefficients are indices representing between 50 and $80 \%$ of the total value of agricultural output for each of the countries. The first column illustrates the impact of "direct" pricing policies. The direct nominal protection rate measures the proportional difference between the domestic producer price and the border price (after adjustment for transport, storage, and other costs and quality differentials) measured at the official exchange rate. Figures for 13 developed countries and two newly industrialized countries (Korea and Taiwan) included in table 1 are averages of those figures obtained by Anderson and Hayami.

Studies financed by the World Bank have provided data on domestic and border prices of agricultural commodities, exchange rate market intervention, and protection afforded to the nonagricultural sector of 18 developing countries from 1960 to 1984 . Direct nominal protection rates show that most countries adopted policies resulting in the equivalent of export taxes on agricultural commodities.' Brazil and Turkey are among countries protecting the agricultural sector because they are traditional importers of food products. The most surprising finding, shown in the second column, is the impact of indirect in-

\footnotetext{
' Developing countries studied contain a much richer and disaggregated data set of protection rates at the level of individual commodities. A simple average of all 18 countries shows subsidies of $3.1 \%$ for staples, $12 \%$ for importables, and $1.5 \%$ for exportables.
} 
Table 1. Nominal Rates of Agricultural Protection

\begin{tabular}{|c|c|c|c|c|}
\hline Country & Period & Direct & Indirect & Total. \\
\hline Switzerland & $55-80$ & 85.8 & & \\
\hline Japan & $55-80$ & 60.5 & & \\
\hline [taly & $55-80$ & 54.5 & & \\
\hline Sweden & $55-80$ & 49.2 & & \\
\hline Germany & $55-80$ & 45.2 & & \\
\hline France & $55-80$ & 32.5 & & \\
\hline The Netherlands & $55-80$ & 28.3 & & \\
\hline United Kingdom & $55-80$ & 27.5 & & \\
\hline Korea & $55-80$ & 18.5 & & \\
\hline Denmark & $55-80$ & 12.3 & & \\
\hline Brazil & $69-83$ & 10.1 & -18.4 & -8.3 \\
\hline Taiwan & $55-80$ & 8.3 & & \\
\hline United States & $55-80$ & 4.5 & & \\
\hline Turkey & $60-83$ & 4.2 & -36.8 & -32.6 \\
\hline Austrália & $55-80$ & 2.8 & & \\
\hline Canada & $55-80$ & 2.5 & & \\
\hline New Zealand & $55-80$ & -1.0 & & \\
\hline Chile & $60-83$ & -1.2 & -20.4 & -21.6 \\
\hline Philippines & $60-86$ & -4.1 & -23.3 & -27.4 \\
\hline Colombia & $60-83$ & -4.8 & -25.2 & -30.0 \\
\hline Pakistan & $60-86$ & -6.4 & -33.1 & -39.5 \\
\hline Sri Lanka & $60-85$ & -9.0 & $-3 l . l$ & -40.1 \\
\hline Malaysia & $60-83$ & -9.4 & -8.2 & -17.6 \\
\hline Morocco & $63-84$ & -15.0 & $-[7.4$ & -32.4 \\
\hline Zambia & $66-84$ & -16.3 & -29.9 & -46.2 \\
\hline Portugal & $60-84$ & $-[6.6$ & -1.2 & -17.8 \\
\hline Argentina & $60-.84$ & $-[7.8$ & -21.3 & -39.1 \\
\hline Dominican Republic & $66-85$ & -18.6 & -21.3 & -39.9 \\
\hline Egypt & $64-84$ & -24.8 & -19.6 & -44.4 \\
\hline Thailand & $62-84$ & -25.1 & -15.0 & -40.1 \\
\hline Cote d'Ivoire & $60-82$ & -25.7 & -23.3 & -490 \\
\hline Ghana & $58-76$ & -26.9 & -32.6 & -59.5 \\
\hline
\end{tabular}

Soutces: Anderson and Hayami; Valdes.

tervention. Indirect effects include both the effect of trade and macroeconomic policies on the exchange rate and the extent of protection afforded to nonagricultural commodities. Discrimination against agricultural commodities in policies external to agriculture has a greater impact on agricultural incentives (a tax equivalent of $23 \%$ ) than do policies aimed directly at agriculture. The results for total price interventions, however, show that the dominant pattern has been one of systematic and sizeable discrimination against agriculture (Valdes).

Our framework suggests the optimal policy choice is conditioned by the contest strength term, $\alpha$, and by the political institutional environment term, $W$. The regulator chooses intervention levels measured by the nominal protection coefficient. The nominal protection coefficient reflects relative group strength and other aspects of the political process, such as equity, that affect the probability of the regulator's remaining in power. Using World Bank data, we estimate a reduced form equation for a set of 18 devel- oping countries with the objective of identifying a relation berween policy choice and factors affecting $\alpha$ and $W$. The dependent variable is the nominal protection coefficient (NPC) for key agricultural products. ${ }^{2}$ The NPC is the multiple by which government policies have raised the domestic value of agricultural output above its value at international prices.

Three variables are used to capture players' relative efficiencies as rent seekers-share of agriculture in GDP, share of agriculture in labor force, and share of agriculture in consumption. We hypothesize that the agricultural sector's rentseeking power declines as the sector's relative size increases. Larger sectors cost more to subsidize, are more difficult to organize, and are more likely to be subsistence sectors, implying they could benefit less from price enhancement.

\footnotetext{
! There are three to sewen products included per county. These producs represent from 50 to $80 \%$ of agriculcutal production. For details, see Fulginiti and Shogren.
} 
Institutional environment, constituent welfare, and other considerations will also affect the probability that a certain sector will be taxed. First, we consider public finance motives for taxing agriculture versus other sectors. Land per capita and productivity per person in agriculture ${ }^{3}$ are used, based upon the hypothesis that the public revenue potential of agricultural taxation rises with the value of agricultural resoutces. It is therefore expected that the greater the labor productivity in agriculture and the more land per capita, the less the protection afforded to agricultural commodities. The share of agriculture in trade and the dummy variables for both exportables and importables are introduced to reflect developing countries' preference of commodity over income taxation. Tradables are easier to tax than nontradables.

Second, we examine equity and distributional motives for caxing agriculture versus other sectors. Two variables are included to capture equity considerations-interventions in the exchange rate market and import substitution policies on the agricultural sector. Currency overvaluation, represented by the ratio of the equilibrium exchange rate to the actual exchange rate, is assumed to link macropolicy and the agricultural sector. The issue is whether there is more pressure for direct protection in proportion to how overvalued the currency becomes, a relation implying the offsetting effect of commodity market intervention. The indirect protection coefficient (NPCI), captures both the effects of import policies protecting the nonagricultural sector and the effects of policies distorting the exchange rate market. These variables are included to allow evaluation of whether the regulator has a tendency to use price procection to redistribute towards the group subject to heavy indirect taxes.

Third, we consider the "food favoritism" motive for taxing agriculture versus other sectors. We hypothesize food products will be subject to tax treatment different from nonfood products as both self-sufficiency in food production and cheap food are often policy objectives in developing countries. To identify possible differential treatment, a dumny variable for food products is introduced.

\footnotetext{
${ }^{3}$ The productivity ratio is an index of the ratio of labor productivity in agticulture to labot product ductivity in agriculture is measured as agricultural output per worker, and labor productivity in industry is approximated as average GDP per worker for the whole economy.
}

Fourth, we include residual effects systematically related to income. The country's wealth, represented by income per capita, captures relative differences in development and is introduced as a proxy for characteristics that are country-specific and have not been captured by variables already included.

Regression analysis is used on a pooled cross section time series data set of 18 countries from. 1960-84 and yields 1,858 data points. Interpretation of the coefficients as causal impacts on protection should be made with caution because explanatory variables might depend upon protection level. Thus we will refer to association rather than to causation, given the possibility of simultaneous equation bias. The regression was run in log-linear form, except for variables representing the relative shares of the agricultural sector and of agricultural trade in the economy.

Table 2 summarizes estimations for different combinations of explanatory variables, regressions (1) to (4). The coefficient of determination indicates that about $60 \%$ of the variation in NPCs among countries and over time are explained. Coefficients of the three proxies of the contest strength term $\alpha$ have the expected sign but are insignificant. This fact does not mean that the sector's relative rent-seeking power is a factor to be disregarded; rather, it might reflect the quality of the variables used to capture $\alpha$. Both variables used to reflect public revenue potential of agricultural taxation - land per capita and labor productivity ratio-show the expected sign and are highly significant. This confirms the belief that agriculturally well-endowed economies tend to discriminate against the sector and extract some land rents.

The share of agricultural trade in GDP seems important inasmuch as ic shows a negative correlation to NPCs and provides evidence that developing countries favor generating revenue by taxing exportable commodities. The greater the proportion of agricultural commodities exported, the more likely regulators will be to tax the sector. Coefficients of both exportable and importable dummies are significant, indicating that importables are protected relative to exportables. The two variables suggesting equity considerations are highly significant, indicating that when the real exchange rate is low, there is pressure for protection. The mote the sector is indirectly taxed, the less it is directly taxed, supporting the hypothesis that a regulator will lessen the burden of the sector under heavy taxation. The coefficient of the food dummy variable is insignificant, suggesting that food and 
Table 2. 1960-84 Regressions for Nominal Protection Coefficients ( $t$-statistics in parentheses)

\begin{tabular}{|c|c|c|c|c|}
\hline Independent variables & (I) & (2) & (3) & (4) \\
\hline \multicolumn{5}{|l|}{ Share of agriculture } \\
\hline in GDP & $\begin{array}{l}-0.012 \\
(-1.03)\end{array}$ & $\begin{array}{r}-0.053 \\
(-1.42)\end{array}$ & & \\
\hline in labor force & & & $\begin{array}{r}-.014 \\
(-0.24)\end{array}$ & \\
\hline in consumption & & & & $\begin{array}{r}-0.002 \\
(-1.13)\end{array}$ \\
\hline Land per capita & $\begin{array}{l}-0.250 \\
(-4.32)\end{array}$ & & & \\
\hline Labor productivity ratio & & $\begin{array}{l}-0.100 \\
(-3.98)\end{array}$ & $\begin{array}{c}-0.110 \\
(-2.86)\end{array}$ & $\begin{array}{c}-0.110 \\
(-4.39)\end{array}$ \\
\hline Share of ag. trade in GDP & & $\begin{array}{r}-0.007 \\
(-5.64)\end{array}$ & $\begin{array}{r}-0.007 \\
(-6.22)\end{array}$ & $\begin{array}{r}-0.009 \\
(-4.65)\end{array}$ \\
\hline Exportables & $\begin{array}{r}-0.260 \\
(-2.96)\end{array}$ & $\begin{array}{c}0.260 \\
(2.88)\end{array}$ & $\begin{array}{c}0.260 \\
(2.95)\end{array}$ & $\begin{array}{r}0.240 \\
(2.62)\end{array}$ \\
\hline Importables & $\begin{array}{r}0.630 \\
(7.28)\end{array}$ & $\begin{array}{c}0.630 \\
(7.22)\end{array}$ & $\begin{array}{c}0.630 \\
(7.27)\end{array}$ & $\begin{array}{c}0.620 \\
(7.10)\end{array}$ \\
\hline Currency overvaluation & $\begin{array}{r}0.210 \\
(3.21)\end{array}$ & $\begin{array}{c}0.220 \\
(3.31)\end{array}$ & $\begin{array}{r}0.190 \\
(3.00)\end{array}$ & \\
\hline NPR indirect & & & & $\begin{array}{r}-0.303 \\
(-3.49)\end{array}$ \\
\hline Food & $\begin{array}{r}-0.014 \\
(-0.52)\end{array}$ & $\begin{array}{c}-0.016 \\
(-0.60)\end{array}$ & $\begin{array}{r}-0.014 \\
(-0.53)\end{array}$ & $\begin{array}{r}-0.017 \\
(-0.65)\end{array}$ \\
\hline Income per capita & $\begin{array}{r}0.052 \\
(3.92)\end{array}$ & $\begin{array}{r}0.034 \\
(1.67)\end{array}$ & $\begin{array}{r}0.047 \\
(1.67)\end{array}$ & $\begin{array}{r}0.048 \\
(2.34)\end{array}$ \\
\hline Intercept & $\begin{array}{r}-0.900 \\
(-5.80)\end{array}$ & $\begin{array}{c}-0.620 \\
(-2.47)\end{array}$ & $\begin{array}{l}-0.810 \\
(-2.18)\end{array}$ & $\begin{array}{r}-1.130 \\
(-5.22)\end{array}$ \\
\hline$R^{2}$ & 0.620 & 0.640 & 0.640 & 0.660 \\
\hline
\end{tabular}

nonfood products are treated alike. The effect of average income is significant and positive, indicating country characteristics related to wealth are not accounted for by the remaining variables.

\section{Summary and Conclusions}

This paper examines policy intervention in agriculture as the outcome of the interaction between self-interested politicians and producer and consumer groups affected by policy choices. According to this approach, politicians competing for support choose the intervention level maximizing their expected utility without jeopardizing the likelihood of their remaining in office. Players in the agricultural and the manufacturing sectors decide how much effort to invest in order to increase the probability of winning the rent created by the regulator's policy choice. Their choice depends upon the strategic timing of effort and on the sharing rule, given the relative strength of the groups involved. Players' strength is captured by a contest bias term hypothesized to depend upon disparities in income endowments between groups, deadweight losses of redistribution, cost of developing and maintaining politically cohesive groups, and availability of tax instruments.

Regression analysis on pooled cross-section, time series data of 18 developing countries reveals that agriculturally well-endowed economies discriminate against agriculture; the higher the proportion of agricultural exports, the more likely that regulators will tax the sector; and as a result of equity considerations, the more a sector is directly taxed, the less it will be indirectly taxed.

Our paper has been motivated in part by Baldwin. By emphasizing the economic self-interest of the political participants, we have attempted to "understand the policy-making process that leads politicians to disregard the advice of economists on issues of international trade. "Economic self-interest almost always dominates when a significant part of an individual's income is affected by policy choice. National and group concerns are likely to dominate personal considerations only when economic self-interest effects are small or unclear. Although we recognize that an individual's social concerns can play an important role in shaping her decisions, our 
framework suggests that economic self-interest explains a certain degree of agricultural protectionism.

\section{References}

Anderson, K., and Y. Hayami. The Political Economy of Agricultural Protection: East Asia in International Perspective, Sydney: Allen and Unwin, 1986

Applebaum, E., and E. Katz. "Seeking Rents by Setting Rents: The Political Economy of Rent Seeking." Econ. J. 97 1986:685-99.

Baik, K., and J. Shogren. "Intergroup Competition with Intrateam Share Competition." Mimeo Appalachian State University, 1991.
Baldwin, R. "The Political Economy of Trade Policy." $J$ Econ. Persp Vol. 3, 4 (1989):119-135

Bates, R., and W. Rogerson. Agriculture In Development: A Coalition Analysis. Pub. Choice 35 (1980):513-27.

Fulginiti, L, and J. Shogren. "Agricultural Protection in Developing Countries." Mimeo. Dept. of Econornics, Iowa State University, $199 \mathrm{l}$.

Olson, M. The Rise and Dectine of Nations, New Haven. Yale University Ptess, 1982.

Tullock, G. "Efficient Rent Seeking." Toward a RentSeeking Society J. Buchanan, R. Tollison, and G. Tullock, eds. College Station: Texas A\&M University Ptess, 97-112.

Valdes, A. "Agricultural Trade and Pricing Policies in Developing Countries: Implications for Policy Reform," paper presented at the XXI Conference of Agricultural Economists, Tokyo, 1991 